University of Vermont

UVM ScholarWorks

College of Agriculture and Life Sciences Faculty

Publications

College of Agriculture and Life Sciences

$1-1-2014$

\title{
Impacts of projected climate change over the Lake Champlain basin in Vermont
}

Justin Guilbert

University of Vermont

Brian Beckage

University of Vermont

Jonathan M. Winter

Columbia University in the City of New York

Radley M. Horton

Columbia University in the City of New York

Timothy Perkins

University of Vermont

See next page for additional authors

Follow this and additional works at: https://scholarworks.uvm.edu/calsfac

Part of the Climate Commons, Community Health Commons, Human Ecology Commons, Nature and Society Relations Commons, Place and Environment Commons, and the Sustainability Commons

\section{Recommended Citation}

Guilbert J, Beckage B, Winter JM, Horton RM, Perkins T, Bomblies A. Impacts of projected climate change over the Lake Champlain Basin in Vermont. Journal of Applied Meteorology and Climatology. 2014 Aug;53(8):1861-75.

This Article is brought to you for free and open access by the College of Agriculture and Life Sciences at UVM ScholarWorks. It has been accepted for inclusion in College of Agriculture and Life Sciences Faculty Publications by an authorized administrator of UVM ScholarWorks. For more information, please contact scholarworks@uvm.edu. 


\section{Authors}

Justin Guilbert, Brian Beckage, Jonathan M. Winter, Radley M. Horton, Timothy Perkins, and Arne Bomblies 


\title{
Impacts of Projected Climate Change over the Lake Champlain Basin in Vermont
}

\author{
Justin Guilbert, * Brian Beckage, ${ }^{+}$Jonathan M. Winter, ${ }^{\#}$ RAdley M. Horton,,,@ \\ Timothy PERKins, ${ }^{+}$AND ARnE Bomblies* \\ * School of Engineering, University of Vermont, Burlington, Vermont \\ ${ }^{+}$Department of Plant Biology, University of Vermont, Burlington, Vermont \\ ${ }^{\#}$ Center for Climate Systems Research, The Earth Institute, Columbia University, New York, New York \\ ${ }^{\circledR}$ NASA Goddard Institute for Space Studies, New York, New York
}

(Manuscript received 7 November 2013, in final form 22 May 2014)

\begin{abstract}
The Lake Champlain basin is a critical ecological and socioeconomic resource of the northeastern United States and southern Quebec, Canada. While general circulation models (GCMs) provide an overview of climate change in the region, they lack the spatial and temporal resolution necessary to fully anticipate the effects of rising global temperatures associated with increasing greenhouse gas concentrations. Observed trends in precipitation and temperature were assessed across the Lake Champlain basin to bridge the gap between global climate change and local impacts. Future shifts in precipitation and temperature were evaluated as well as derived indices, including maple syrup production, days above $32.2^{\circ} \mathrm{C}\left(90^{\circ} \mathrm{F}\right)$, and snowfall, relevant to managing the natural and human environments in the region. Four statistically downscaled, biascorrected GCM simulations were evaluated from the Coupled Model Intercomparison Project phase 5 (CMIP5) forced by two representative concentration pathways (RCPs) to sample the uncertainty in future climate simulations. Precipitation is projected to increase by between 9.1 and $12.8 \mathrm{~mm} \mathrm{yr}^{-1} \mathrm{decade}^{-1}$ during the twenty-first century while daily temperatures are projected to increase between $0.43^{\circ}$ and $0.49^{\circ} \mathrm{C} \mathrm{decade}^{-1}$. Annual snowfall at six major ski resorts in the region is projected to decrease between $46.9 \%$ and $52.4 \%$ by the late twenty-first century. In the month of July, the number of days above $32.2^{\circ} \mathrm{C}$ in Burlington, Vermont, is projected to increase by over 10 days during the twenty-first century.
\end{abstract}

\section{Introduction}

The Lake Champlain basin is a $21326-\mathrm{km}^{2}$ watershed on the U.S.-Canada border that spans Vermont, New York, and Quebec. Economic activities associated with the watershed, including tourism, agriculture, and recreational use, are extremely important to the region, and sensitive to climate change. The region has recently been impacted by extreme weather events including significant flooding in 2011 from both heavy spring rainfall and Tropical Storm Irene in late summer. These precipitation events resulted in extensive damage to public infrastructure and private property and highlight the potential impacts of climate change (Pealer 2012).

Corresponding author address: Justin Guilbert, 23 Mansfield Ave., Burlington, VT 05401.

E-mail: jguilber@uvm.edu
Adaptation planning can be enhanced by reliable climate projections at local governance scales.

Regional changes in temperature and precipitation have already been observed in the region. Keim et al. (2005) found positive trends in precipitation across the northeastern (NE) United States but did note that trends differ across subsets of this region. Groisman et al. (2005) found spatially divergent precipitation trends within the Lake Champlain basin, a subregion of the NE United States, with linear trends between 1900 and 2002 of approximately $+10 \%$ in the northern section but $-10 \%$ in the southern part of the watershed. The magnitude of historical precipitation change in the Lake Champlain basin increased by $8 \%-38 \%$ at low and high elevations, respectively, over the 40 -yr period from 1963 to 2003 (Beckage et al. 2008).

Several studies have examined climate change projections across the northeastern United States at broad regional scales. Hayhoe et al. (2007) used nine general 


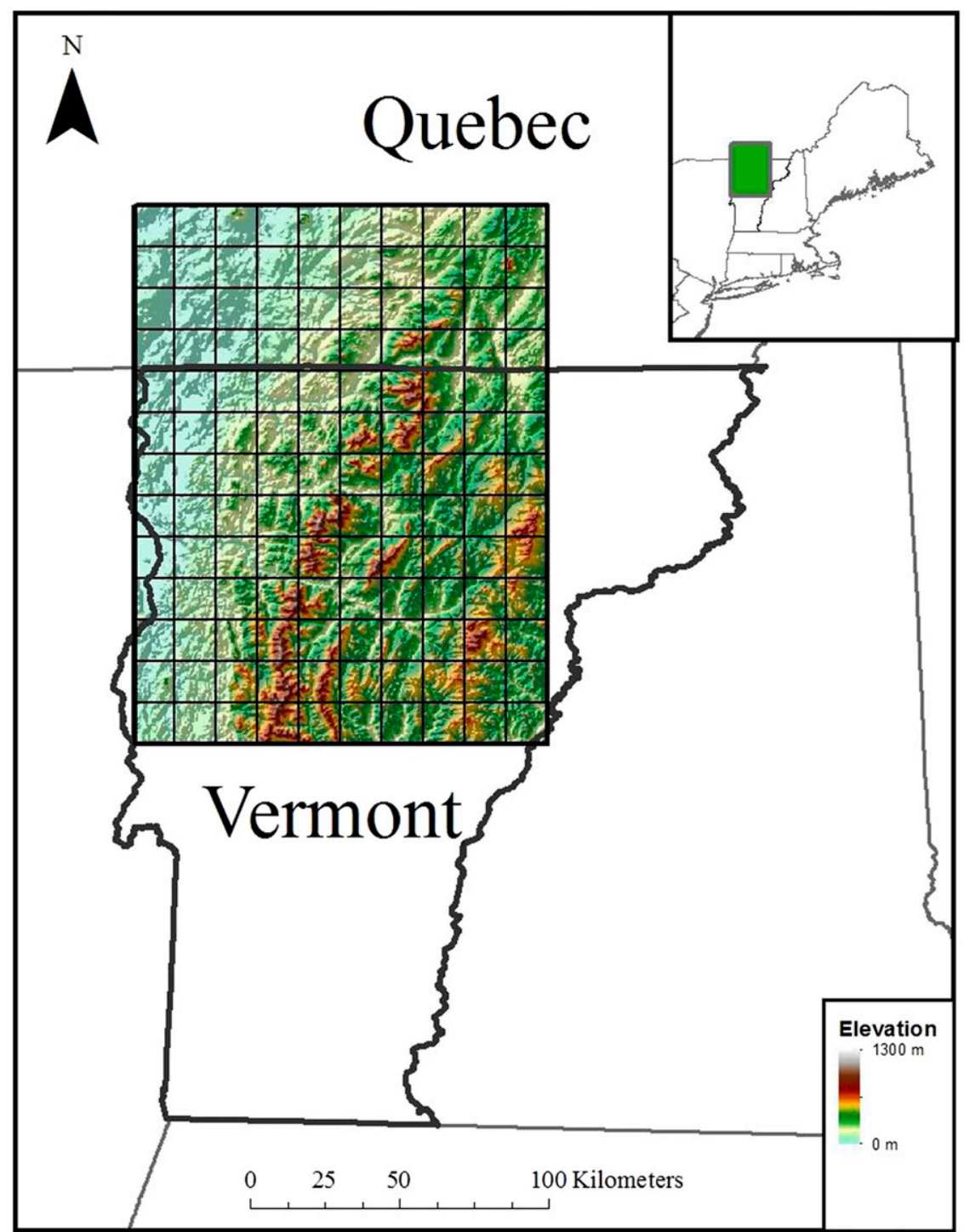

FIG. 1. Study region including northern Vermont and southern Quebec.

circulation models (GCMs) and two emissions scenarios from the Intergovernmental Panel on Climate Change Special Report on Emissions Scenarios (SRES) to project $4.5^{\circ}$ and $2.9^{\circ} \mathrm{C}$ mean annual temperature increases under the $\mathrm{A} 2$ and $\mathrm{B} 1$ emissions scenarios, respectively, by the end of the century (2070-99) in the NE United States. Ahmed et al. (2012) used six GCMs and four regional climate models (RCMs) that were statistically downscaled and bias corrected to project that the annual number of frost days would be reduced by 25 days and the growing-season length would increase by 20 days by midcentury (2046-65) in the NE United States. This study found that maximum 5-day precipitation increased in some areas of the Lake Champlain basin while decreasing in others. Rawlins et al. (2012) used nine RCM simulations forced with the SRES A2 emissions scenario from the North American Regional Climate Change Assessment Program (NARCCAP) to compare historical and mid- to late-century (2041-70) NE U.S. temperature and precipitation. The average annual increases in temperature and precipitation across this time period were $2.6^{\circ} \mathrm{C}$ and $6 \%$, respectively.

Regional climate change impacts are potentially highly consequential for a number of industries, including maple syrup production, dairy farming, and winter recreation (e.g., skiing and snowmobiling; Horton et al. 2014). Moreover, state- and local-level policy makers increasingly consider climate data for future planning (Horton et al. 2014). For example, water resources, transportation infrastructure, and public health adaptations 

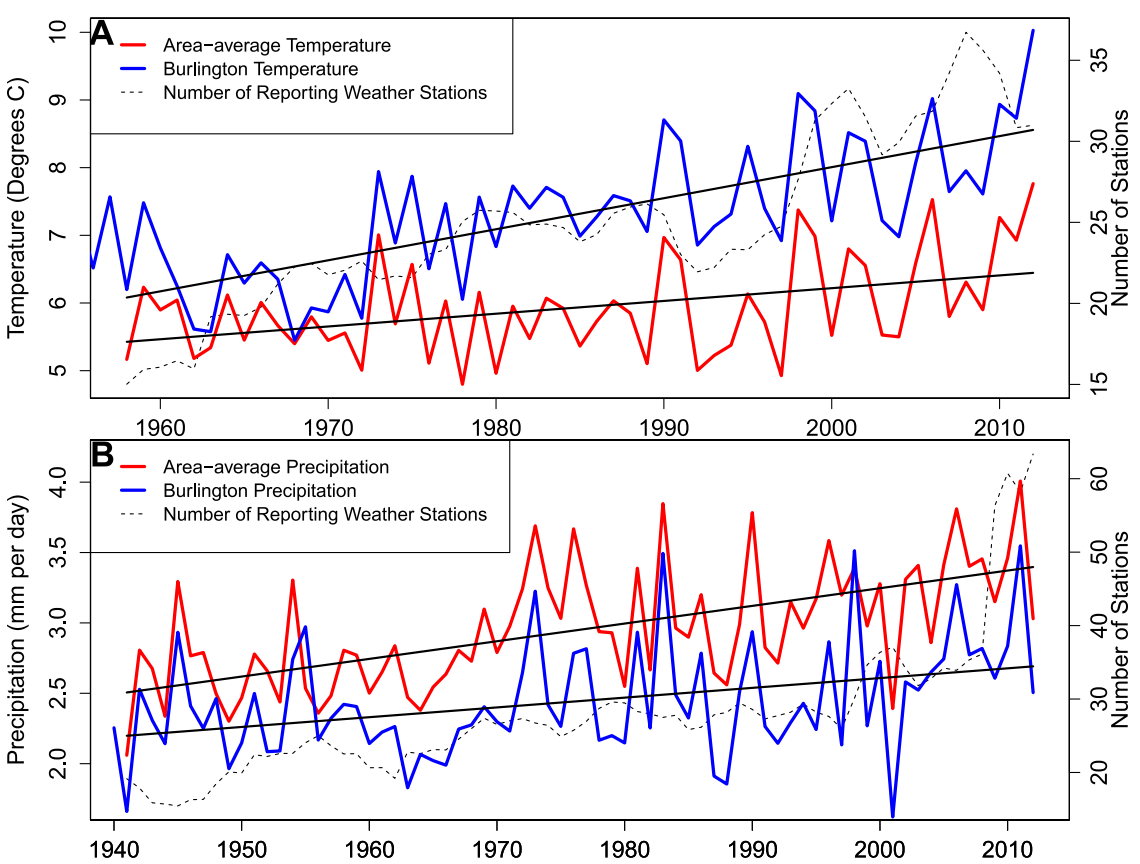

FIG. 2. Historic trends in annual (a) temperature and (b) precipitation from weather stations across the study region.

may rely heavily on predictions of expected future climate. This study derives projected climate metrics, detailed below, that can be used to inform decisions related to agriculture, tourism, and human health.

\section{Methods}

The range of projected climate change for the Lake Champlain basin in Vermont was examined using statistically downscaled GCM projections. Four GCMs and two emission scenarios were utilized from the recent Coupled Model Intercomparison Project phase 5 (CMIP5) model runs. Simulated future changes in climate were assessed with respect to historical precipitation and temperature from National Climatic Data Center (NCDC; Menne et al. 2012) stations. Projected changes in stakeholderrelevant climate metrics were derived. Metrics related to agriculture and dairy include a heat index, an aridity index, and growing-season length. Human-health-related metrics include heating/cooling requirements, heat index, and days above $32.2^{\circ} \mathrm{C}\left(90^{\circ} \mathrm{F}\right)$. Days suitable for maple syrup production, freezing days, and snowfall metrics were developed in relation to the maple syrup and ski industries.

\section{a. Study region}

The Lake Champlain basin is primarily composed of forested and agricultural land. A network of rivers and streams is distributed throughout the region, and the north-south-oriented Green Mountains form the major topographic feature of the study region. Elevations in the Lake Champlain basin range from $30 \mathrm{~m}$ above mean sea level (MSL) on Lake Champlain to $1340 \mathrm{MSL}$ at the top of Mount Mansfield, the highest point in Vermont, over a distance of less than $50 \mathrm{~km}$ (Fig. 1).

\section{b. Climate data}

Historical meteorological station data from throughout the study region were acquired from the Global Historical Climatology Network (GHCN; Menne et al. 2012). This dataset is at a daily resolution and consists of three variables: precipitation, maximum temperature, and minimum temperature. The full records for 132 stations were downloaded. The periods of record were 1875-present and 1884-present for precipitation and temperature, respectively.

Data for future projections of temperature and precipitation were from four realizations of a CMIP5 multimodel ensemble, which was downscaled using a method of bias correction with constructed analogs (BCCA; Brekke et al. 2013). BCCA was chosen for its high spatial $\left(1 / 8^{\circ}\right)$ and temporal (daily) resolution. BCCA methods leverage observed climate data to both bias correct and statistically downscale GCM data. A full description of the BCCA methodology can be found in Hidalgo et al. (2008), Maurer and Hidalgo (2008), and Maurer et al. (2010). Relative to Coupled Model Intercomparison Project phase 3 (CMIP3), CMIP5 models generally have higher spatial resolution and contain a number of 

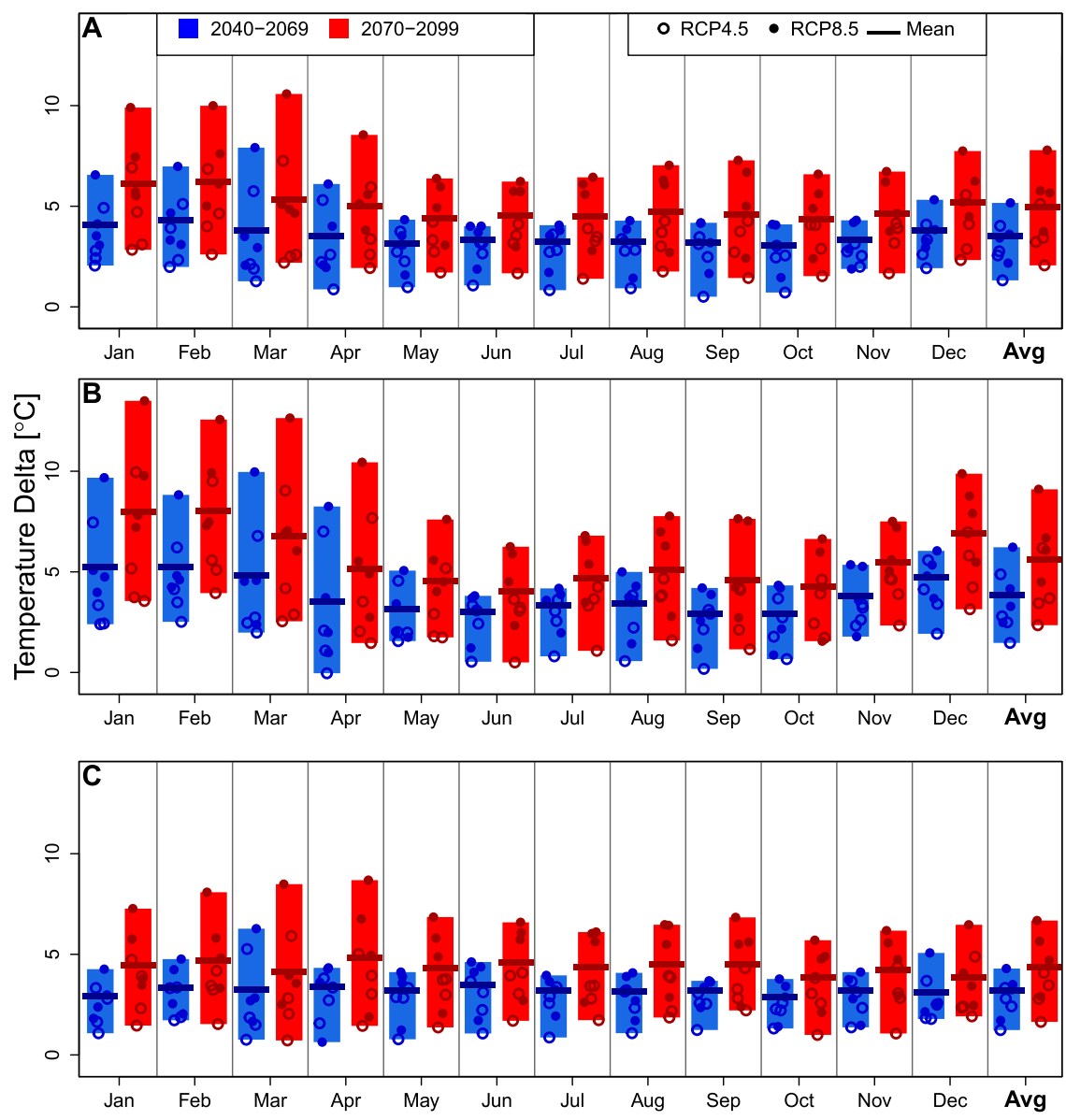

FIG. 3. Projected increase in (a) mean, (b) the 0.05 quantile, and (c) the 0.95 quantile for 2040 69 and 2070-99 for RCP 4.5 and 8.5 relative to the 1970-99 base period and four GCMs.

improvements that have led to better simulations of some climate features (Knutti and Sedláček 2012; Stroeve et al. 2012). CMIP5 models are driven by representative concentration pathways (RCPs; Moss et al. 2010), which are a set of greenhouse gas emission, aerosol, and land-use changes scenarios developed as an input for climate modeling experiments. CMIP5 simulations use four RCPs distinguished by their radiative forcing at the end of the century. The radiative forcing in these scenarios ranges from 2.6 to $8.5 \mathrm{~W} \mathrm{~m}^{-2}$, where larger numbers represent higher emissions scenarios. Additional details on the construction of RCPs can be found in Moss et al. (2010). In this study, RCPs 4.5 and 8.5 were used to capture moderate and high climate change scenarios for purposes of adaptive planning.

Daily minimum temperature, daily maximum temperature, and daily precipitation were analyzed across three time periods: 1961-2000, 2040-69, and 2070-99. All three time periods were assessed using four GCMs, each forced by two RCPs. GCMs were selected to capture the range of potential future temperature and precipitation based on a preliminary analysis of the entire BCCA ensemble of simulations under RCP 8.5 for the 2070-99 period. Future climate simulations (2070-99) were ranked from wettest to driest and warmest to coolest, with the top and bottom $10 \%$ of the ranked GCMs considered for selection. Priority among GCMs ranking in the top and bottom $10 \%$ of the temperature and precipitation simulations was given to well-established models that were available for both CMIP3 and CMIP5, maximizing opportunities for comparison of results to existing andfuture studies. After this process, four GCMs were selected: 1) the Commonwealth Scientific and Industrial Research Organisation Mark 3.6.0 (CSIRO-MK3-6-0.1; wettest 10\%); 2) L'Institut Pierre-Simon Laplace Coupled Model, version 5, coupled with the Nucleus for European Modelling of the Ocean model (NEMO), mid resolution (IPSL-CM5A-MR.1; driest 10\%); 3) Japan Agency for Marine-Earth Science and Technology, Atmosphere and Ocean Research Institute at the University of Tokyo, and National Institute for Environmental Studies Model for Interdisciplinary Research on Climate, Earth System 
TABLE 1. In comparison with the base period, the change in the mean and quantiles of temperature and precipitation are shown for the mid- and late twenty-first century. Seasons are defined as March-May for spring, June-August for summer, September-November for autumn, and December-February for winter.

\begin{tabular}{|c|c|c|c|c|c|c|c|c|}
\hline & & \multirow[b]{2}{*}{ Season } & \multicolumn{3}{|c|}{ 2040-69 } & \multicolumn{3}{|c|}{ 2070-99 } \\
\hline & & & $2.5 \%$ & $50 \%$ & $97.5 \%$ & $2.5 \%$ & $50 \%$ & $97.5 \%$ \\
\hline \multirow{15}{*}{$\begin{array}{l}\text { Change in temperature }\left({ }^{\circ} \mathrm{C}\right) \text { from base period } \\
(1970-99)\end{array}$} & \multirow[t]{5}{*}{ Mean } & Annual & 2.9 & 3.1 & 3.3 & 4.3 & 4.6 & 4.9 \\
\hline & & Spring & 2.7 & 3.1 & 3.5 & 4.1 & 4.5 & 5.0 \\
\hline & & Summer & 2.6 & 2.9 & 3.1 & 3.9 & 4.2 & 4.5 \\
\hline & & Autumn & 2.5 & 2.8 & 3.1 & 3.8 & 4.2 & 4.5 \\
\hline & & Winter & 3.2 & 3.7 & 4.2 & 5.0 & 5.5 & 6.0 \\
\hline & \multirow[t]{5}{*}{5 th } & Annual & 3.2 & 3.5 & 3.8 & 4.9 & 5.3 & 5.6 \\
\hline & & Spring & 2.9 & 3.5 & 4.0 & 4.6 & 5.1 & 5.7 \\
\hline & & Summer & 2.5 & 2.9 & 3.3 & 3.8 & 4.2 & 4.6 \\
\hline & & Autumn & 2.4 & 2.8 & 3.3 & 3.9 & 4.4 & 4.9 \\
\hline & & Winter & 4.1 & 4.7 & 5.3 & 6.6 & 7.3 & 7.9 \\
\hline & \multirow[t]{5}{*}{95 th } & Annual & 2.6 & 2.8 & 3.0 & 3.8 & 4.0 & 4.2 \\
\hline & & Spring & 2.4 & 2.9 & 3.4 & 3.5 & 4.0 & 4.6 \\
\hline & & Summer & 2.6 & 2.9 & 3.2 & 3.8 & 4.1 & 4.4 \\
\hline & & Autumn & 2.3 & 2.7 & 3.1 & 3.4 & 3.8 & 4.2 \\
\hline & & Winter & 2.2 & 2.8 & 3.3 & 3.4 & 4.0 & 4.5 \\
\hline \multirow{15}{*}{$\begin{array}{l}\text { Change in precipitation }\left(\mathrm{mm} \mathrm{day}^{-1}\right) \text { from } \\
\text { base period (1970-99) }\end{array}$} & \multirow[t]{5}{*}{ Mean } & Annual & 0.2 & 0.2 & 0.3 & 0.2 & 0.3 & 0.3 \\
\hline & & Spring & 0.1 & 0.2 & 0.4 & 0.3 & 0.4 & 0.6 \\
\hline & & Summer & 0.1 & 0.3 & 0.5 & 0.1 & 0.3 & 0.5 \\
\hline & & Autumn & -0.1 & 0.1 & 0.3 & 0.0 & 0.2 & 0.4 \\
\hline & & Winter & 0.1 & 0.2 & 0.4 & 0.2 & 0.3 & 0.4 \\
\hline & \multirow[t]{5}{*}{ 95th } & Annual & 0.8 & 1.1 & 1.4 & 1.3 & 1.5 & 1.8 \\
\hline & & Spring & 0.5 & 1.1 & 1.8 & 1.1 & 1.8 & 2.5 \\
\hline & & Summer & 0.4 & 1.2 & 2.0 & 0.7 & 1.4 & 2.2 \\
\hline & & Autumn & 0.0 & 0.8 & 1.7 & 0.4 & 1.3 & 2.3 \\
\hline & & Winter & 0.3 & 0.9 & 1.5 & 0.5 & 1.1 & 1.7 \\
\hline & \multirow[t]{5}{*}{ 99th } & Annual & 2.0 & 2.5 & 2.9 & 2.9 & 3.4 & 3.9 \\
\hline & & Spring & 0.9 & 1.8 & 2.8 & 1.7 & 2.6 & 3.7 \\
\hline & & Summer & 1.2 & 2.4 & 3.7 & 1.4 & 2.6 & 3.8 \\
\hline & & Autumn & 0.5 & 1.8 & 3.1 & 1.4 & 2.8 & 4.3 \\
\hline & & Winter & 0.5 & 1.4 & 2.2 & 1.3 & 2.2 & 3.2 \\
\hline
\end{tabular}

Model (MIROC-ESM.1; warmest 10\%); and 4) Institute of Numerical Mathematics Coupled Model, version 4.0 (INMCM4.1; coolest 10\%).

Historical climate records and future climate projections for temperature and precipitation were compiled for a portion of the Lake Champlain basin. This area spans from $43^{\circ} 56^{\prime} 15^{\prime \prime}$ to $45^{\circ} 26^{\prime} 15^{\prime \prime} \mathrm{N}$ and from $72^{\circ} 11^{\prime} 15^{\prime \prime}$ to $73^{\circ} 18^{\prime} 45^{\prime \prime} \mathrm{W}$ (Fig. 1). The rectangular area is covered by a $10 \times 13$ grid of $1 / 8^{\circ}$ cells. The outer dimensions of this area are approximately $100 \mathrm{~km} \times 180 \mathrm{~km}$. At the latitude of the study region, $1 / 8^{\circ}$ cells are approximately $10 \mathrm{~km} \times 14 \mathrm{~km}$.

\section{c. Climate data analysis}

\section{1) Historical TRENDS}

For each GHCN station, all missing values were removed, and minimum and maximum daily temperatures were averaged to calculate a daily mean temperature. Daily temperature and precipitation data were averaged across all available stations for each day by a simple arithmetic mean. Annual means and quantiles for temperature and precipitation were calculated from the distribution of average daily values for a given year. Only the years in which data from 15 or more stations were available were used. These periods were 19412012 for precipitation and 1958-2012 for temperature.

\section{2) Deltas And Climate PROJections}

Daily climate data were averaged to produce a seasonal cycle (i.e., composed of mean monthly values) for every grid cell within the study region. This was repeated for each BCCA scenario using the same four GCMs and two RCPs for both temperature and precipitation across all three time periods. Temperature change factors, or "deltas," were calculated for each grid cell by subtracting the seasonal cycle in the historical period from the respective seasonal cycles in each of the two future periods. Each value represents the projected temperature change in degrees Celsius for a particular cell and month for a given future period. Projections of changes in precipitation were calculated in a similar manner except that ratios of change ("delta factors") were 

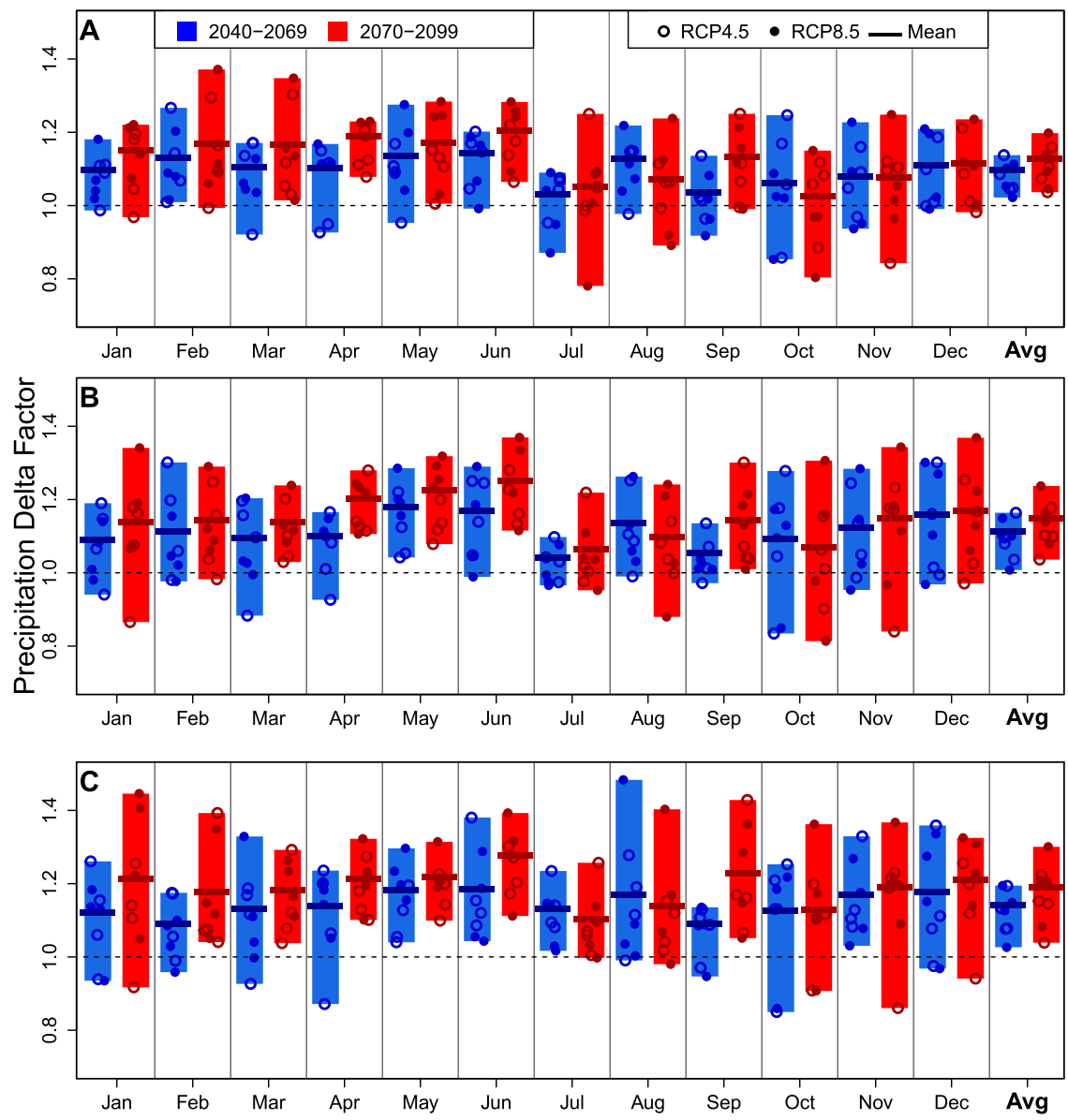

FIG. 4. Projected changes in (a) mean, (b) the 0.95 quantile, and (c) the 0.99 quantile of daily precipitation for 2040-69 and 2070-99 for four GCMs under RCP 4.5 and 8.5 relative to the 1970-99 base period.

used. Temperature deltas were added to the observed daily dataset (Maurer et al. 2010) for the study region for every cell to provide a future temperature projection in each grid cell. The delta factors for precipitation were multiplied by the observed daily precipitation data for every cell to provide a projection for future precipitation. The delta method was applied to examine projected changes in mean temperature and precipitation, as well as extremes in temperature (5th and 95th quantiles) and precipitation (95th and 99th quantiles), to explore changes in extremes.

\section{3) RATIO OF PRECIPITATION TO POTENTIAL EVAPOTRANSPIRATION}

To gauge potential future impacts on vegetation and agriculture, the ratio of precipitation to potential evapotranspiration (rPPET) was calculated. Potential evapotranspiration (PET) was calculated using Thornthwaite's (1948) Eq. (1), which depends upon average daily and monthly temperatures $T_{\alpha}$ and $T_{\alpha i}$, average day length by month $L$, and number of days per month $N$ :

$$
\mathrm{PET}=16 \frac{L}{12} \frac{N}{30}\left(\frac{10 T_{\alpha}}{I}\right)^{\alpha}
$$

where

$$
\begin{aligned}
\alpha= & \left(6.75 \times 10^{-7}\right) I^{3}-\left(7.71 \times 10^{-5}\right) I^{2} \\
& +\left(1.792 \times 10^{-2}\right) I+0.49239
\end{aligned}
$$

and

$$
I=\sum_{i=1}^{12}\left(T_{\alpha i} / 5\right)^{1.514}
$$

4) DAYS BELOW FREEZING, DAYS ABOVE $32.2^{\circ} \mathrm{C}$, SNOWFALL, GROWING SEASON, AND DAYS WITH MAPLE SYRUP PRODUCTION

The number of freezing days per month was determined by counting the number of days per month for 

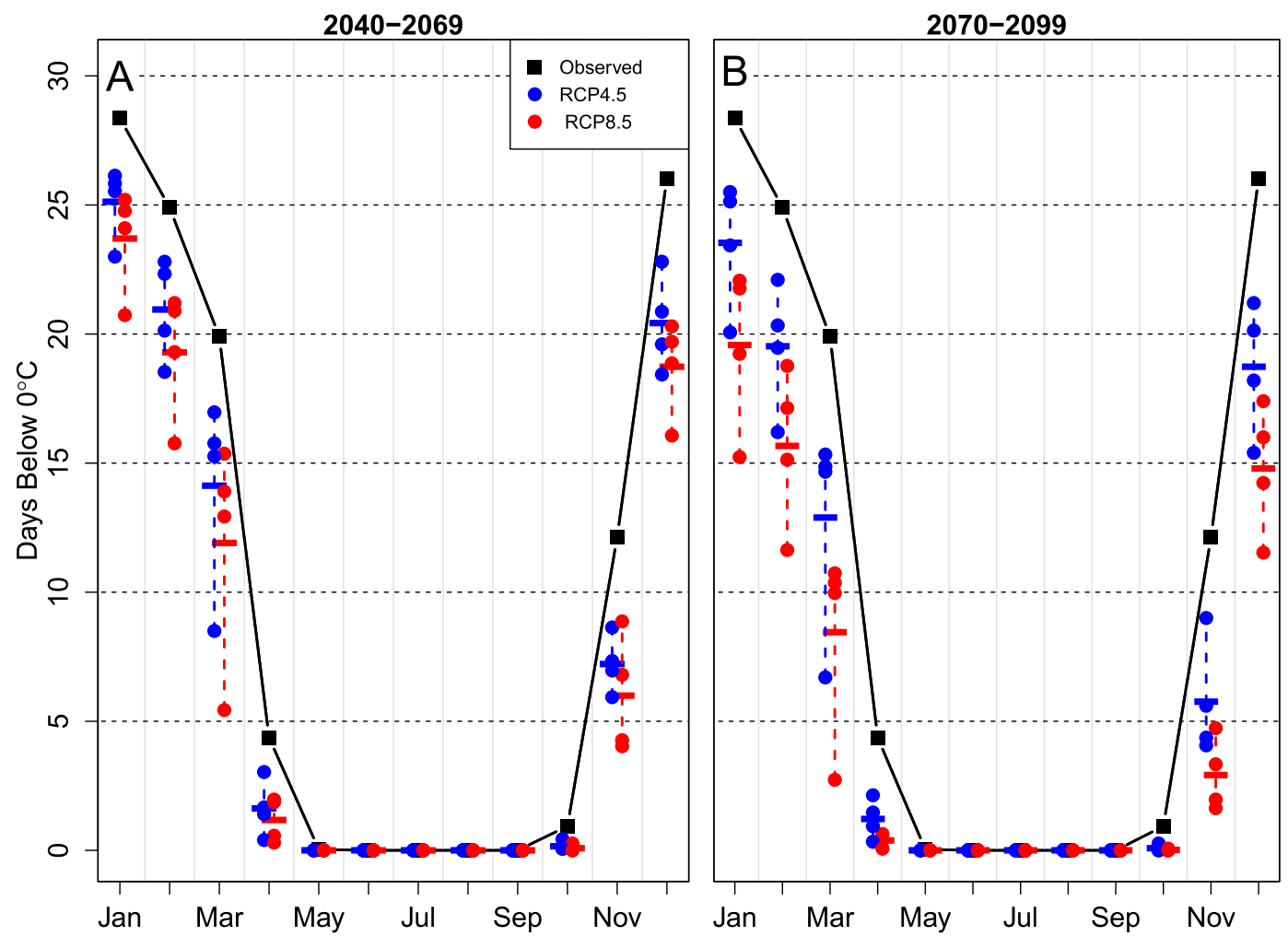

FIG. 5. The projected number of freezing days per month for (a) 2040-69 and (b) 2070-99 for RCP 4.5 and 8.5 relative to the $1970-99$ base period.

which the average temperature was below $0^{\circ} \mathrm{C}$. These data were used to calculate the mean number of freezing days per month and year for each time period. This method was also used to calculate the number of days where the maximum daily temperature was above $32.2^{\circ} \mathrm{C}\left(90^{\circ} \mathrm{F}\right)$ per month. This was calculated for the grid cell within the region that contained Burlington, Vermont, to assess the heat wave impacts of climate change on a population center.

A metric for snowfall was calculated for four grid cells, which were determined to contain six of the region's largest ski resorts. This calculation was based on days with an average temperature below freezing combined with projections of daily precipitation. If a particular day was below freezing, a table from the NCDC (2013) was used to determine the ratio of snowfall to total precipitation. This table contains values ranging from 10 to 100 , depending on the temperature. This ratio was then multiplied by the spatially averaged precipitation across the four selected cells for the respective day to convert precipitation to snowfall. The values calculated through this method were averaged over each 30 -yr period to determine the monthly projected snowfall. Monthly projected snowfall was summed from October through April to determine the projected cumulative seasonal snowfall.
The length of the growing season was determined by finding the maximum time between two days whose minimum temperatures were below $0^{\circ} \mathrm{C}$ for each of the years within each 30-yr period.

Days in which sugar maple trees are likely to exude sap suitable for maple syrup production were determined based on daily minimum and maximum temperatures. Days with a minimum temperature below $-1.1^{\circ} \mathrm{C}\left(30^{\circ} \mathrm{F}\right)$ and maximum temperature above $2.2^{\circ} \mathrm{C}\left(36^{\circ} \mathrm{F}\right)$ were considered suitable for maple syrup production (Skinner et al. 2010). The number of suitable days was calculated for every month for the 30 -yr period.

\section{5) HeAting AND COOLING REQUiREMENTS AND HEAT INDEX}

Heating and cooling requirements were determined based on daily average temperatures across the region. Days with temperatures below $20^{\circ} \mathrm{C}\left(68^{\circ} \mathrm{F}\right)$ were deemed to require heating and days with temperatures above $25.6^{\circ} \mathrm{C}$ $\left(78^{\circ} \mathrm{F}\right)$ were deemed to require cooling based on a human comfort index (Burroughs and Hansen 2004). To quantify the amount of heating and cooling required, the numbers of degrees per day above or below the cooling and heating limits were summed monthly and annually to create heating and cooling requirements in degree days (DDs). 


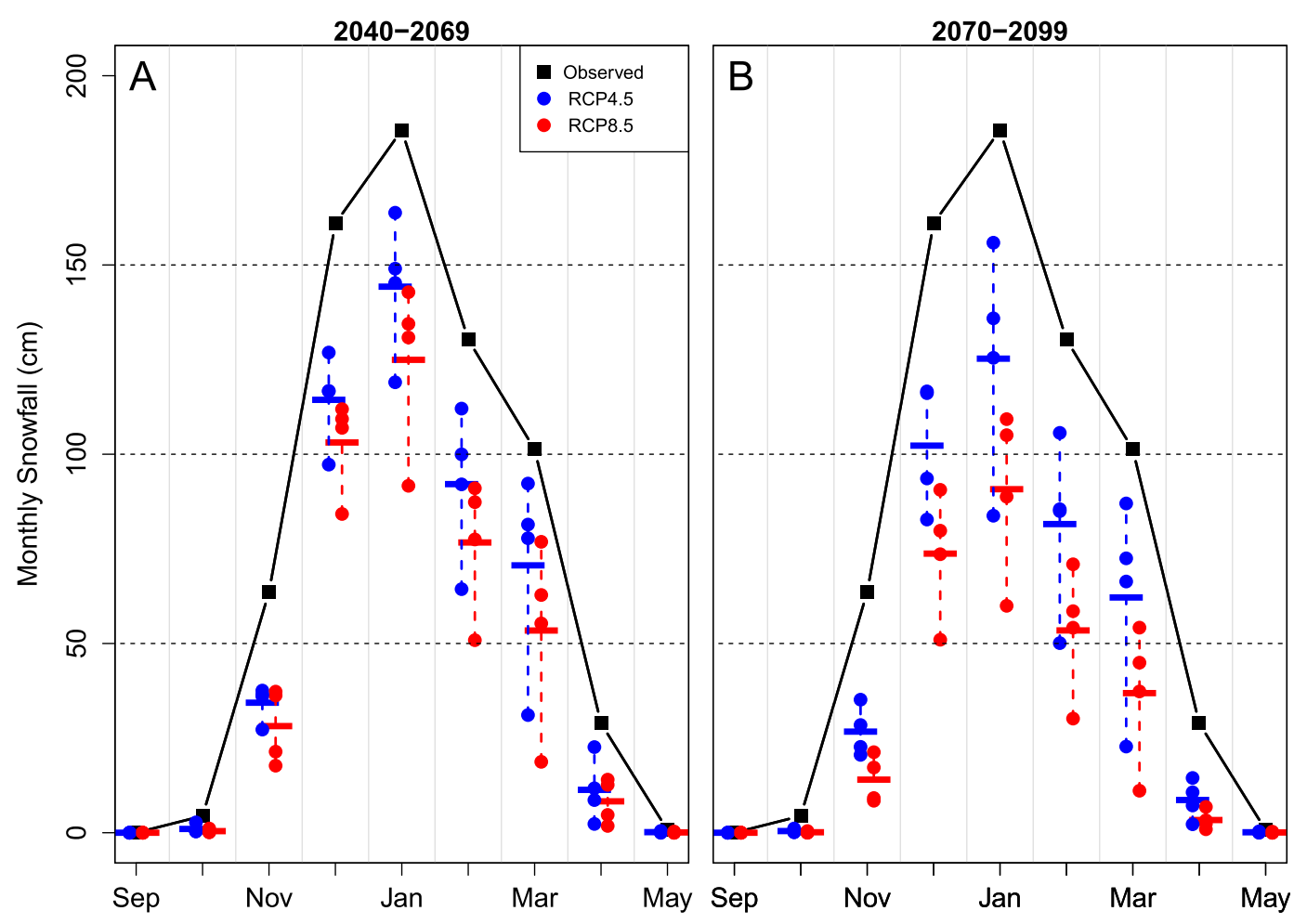

FIG. 6. As in Fig. 5, but for monthly snowfall.

A heat index was calculated in DDs. The heat index calculations utilized the same formula as National Oceanic and Atmospheric Administration (NOAA), which uses temperature and relative humidity. The heat index, as per NOAA, is calculated for days whose maximum daily temperature is greater than $26.7^{\circ} \mathrm{C}\left(80^{\circ} \mathrm{F}\right)$. Daily dewpoint temperatures were calculated using an empirical model, which requires average minimum and maximum daily temperature (Kimball et al. 1997). Relative humidity was calculated from the resulting dewpoint temperature and average daily temperature (Lawrence 2005).

\section{d. Bayesian statistics}

Bayesian credible intervals were computed for the delta factors of temperature, precipitation, temperature quantiles, precipitation quantiles, and derived metrics for future periods (Lavine 2009). Thirty monthly replicates exist for each of the eight RCP-by-GCM combinations as well as the 30 observations for each month during the base period. It was assumed that these replicates for both the future and historic periods were normally distributed with different but unknown means and variances. The posterior distributions of the difference (e.g., for temperature) or ratio (e.g., for precipitation) of these population means were estimated and reported at the $95 \%$ credible interval on these metrics. Credible intervals were calculated using the "Just Another Gibbs Sampler" program (Plummer 2003), which generates samples from the posterior distribution using Markov chain Monte Carlo simulation.

\section{Results}

\section{a. Observed trends}

Averaged GHCN daily data across the region indicated an increase in temperature between 1958 and 2012 and an increase in precipitation between 1941 and 2012 (Fig. 2). Average temperature increased by $0.19^{\circ} \mathrm{C} \mathrm{decade}^{-1}$, which is nearly 2 times the rate of $1.02^{\circ} \mathrm{C}$ century ${ }^{-1}$ found by Trombulak and Wolfson (2004) for the period 1903-2000. Annual precipitation increased by $45.8 \mathrm{~mm} \mathrm{decade}^{-1}$, which is higher than other studies that include this region (Keim et al. 2005; Hayhoe et al. 2007). Keim et al. (2005) found increases in annual precipitation between 8 and $39 \mathrm{~mm} \mathrm{decade}^{-1}$ across Vermont, while Hayhoe et al. (2007) estimated increases in annual precipitation of approximately $7 \mathrm{~mm} \mathrm{decade}^{-1}$. During the time period 1941-2012, the number of operating weather stations increased by $106 \%$ for temperature and $230 \%$ for precipitation. The 0.05 and 0.95 quantiles of temperature increase by $0.50^{\circ}$ and $0.05^{\circ} \mathrm{Cdecade}^{-1}$, respectively. The 0.95 and 0.99 quantiles of precipitation increase by 0.38 and $0.48 \mathrm{~mm}_{\text {day }}{ }^{-1}$ decade $^{-1}$, respectively. 
TABLE 2. Relevant climate change metrics for the base period and the mid and late twenty-first century. Seasons are defined as in Table 1.

\begin{tabular}{|c|c|c|c|c|c|c|c|c|}
\hline \multirow[b]{2}{*}{ Metric } & \multirow[b]{2}{*}{ Season } & \multirow[b]{2}{*}{ Base Avg } & \multicolumn{3}{|c|}{$2040-69$} & \multicolumn{3}{|c|}{ 2070-99 } \\
\hline & & & $2.5 \%$ & $50 \%$ & $97.5 \%$ & $2.5 \%$ & $50 \%$ & $97.5 \%$ \\
\hline \multirow[t]{4}{*}{ Freezing days (day) } & Annual & 117 & 83 & 85 & 87 & 69 & 72 & 74 \\
\hline & Nov-Dec & 38 & 25 & 26 & 27 & 20 & 21 & 22 \\
\hline & Jan-Feb & 53 & 43 & 45 & 46 & 38 & 39 & 41 \\
\hline & Mar-Apr & 24 & 13 & 14 & 15 & 11 & 11 & 12 \\
\hline \multirow[t]{4}{*}{ Snowfall $(\mathrm{cm})$} & Annual & 676 & 413 & 432 & 450 & 321 & 340 & 359 \\
\hline & Autumn & 68 & 29 & 32 & 35 & 18 & 21 & 23 \\
\hline & Winter & 477 & 305 & 328 & 351 & 242 & 263 & 285 \\
\hline & Spring & 131 & 64 & 72 & 80 & 48 & 56 & 63 \\
\hline Above $32.2^{\circ} \mathrm{C}$ (day) & Annual & 6 & 23 & 24 & 25 & 35 & 37 & 40 \\
\hline \multirow[t]{2}{*}{ Heat index $\left({ }^{\circ} \mathrm{Cday}^{-1}\right)$} & Annual & 130 & 449 & 475 & 501 & 540 & 553 & 555 \\
\hline & Summer & 118 & 389 & 416 & 442 & 597 & 642 & 687 \\
\hline Growing season (day) & Annual & 141 & 166 & 169 & 171 & 181 & 184 & 186 \\
\hline \multirow[t]{4}{*}{ Maple sap production (day) } & Annual & 60 & 52 & 53 & 54 & 48 & 49 & 50 \\
\hline & Autumn & 19 & 12 & 12 & 13 & 9 & 9 & 10 \\
\hline & Winter & 14 & 20 & 21 & 23 & 22 & 23 & 24 \\
\hline & Spring & 27 & 18 & 19 & 20 & 15 & 16 & 17 \\
\hline \multirow[t]{4}{*}{ Heating requirements $\left({ }^{\circ} \mathrm{C} \mathrm{day}^{-1}\right)$} & Annual & 5294 & 4216 & 4307 & 4398 & 3785 & 3885 & 3985 \\
\hline & Autumn & 1153 & 897 & 916 & 935 & 778 & 800 & 823 \\
\hline & Winter & 2527 & 2159 & 2197 & 2235 & 1992 & 2033 & 2074 \\
\hline & Spring & 1395 & 1078 & 1106 & 1133 & 965 & 995 & 1024 \\
\hline \multirow[t]{4}{*}{ Cooling requirements $\left({ }^{\circ} \mathrm{C}\right.$ day $\left.^{-1}\right)$} & Annual & 0 & 11 & 13 & 15 & 35 & 40 & 46 \\
\hline & Spring & 0 & 0 & 0 & 0 & 1 & 1 & 1 \\
\hline & Summer & 0 & 10 & 12 & 14 & 32 & 37 & 43 \\
\hline & Autumn & 0 & 0 & 0 & 1 & 1 & 2 & 3 \\
\hline rPPET (ratio) & Summer & 1.14 & 1.10 & 1.15 & 1.20 & 1.06 & 1.11 & 1.16 \\
\hline
\end{tabular}

The record precipitation year (2011) totaled $1.46 \mathrm{~m}$ of precipitation, which is 2.47 standard deviations above the period mean of $1.08 \mathrm{~m}$ of precipitation from 1948 to 2012 . Nine of the 10 warmest years in the temperature record have occurred between 1990 and 2012, with the warmest year on record occurring in 2012. Trends in temperature and precipitation could be affected by changes in the spatial and topographic distributions of climate stations with time. To support the trends found for the region, Burlington, one of the longest and most reliable standing records of weather in the region, was used. Burlington's weather station supported the regional findings, showing positive trends in both temperature and precipitation (Fig. 2).

\section{b. Climate projections}

Temperature and precipitation projections are qualitatively consistent with the increases seen in the historical station data. Annual average temperature is projected to increase by $3.1^{\circ} \mathrm{C}$ by midcentury and $4.6^{\circ} \mathrm{C}$ by late in the twenty-first century, which is consistent with Hayhoe et al.'s (2007) estimate of between $+2.1^{\circ}$ and $+2.9^{\circ} \mathrm{C}$ for midcentury and between $+2.9^{\circ}$ and $+5.3^{\circ} \mathrm{C}$ for late in the century. Similarly, all monthly estimates of temperature change were significantly different from zero using a $95 \%$ Bayesian credible interval (Fig. 3). The 0.05 quantile of daily temperature is projected to increase $3.5^{\circ} \mathrm{C}$ by midcentury and $5.3^{\circ} \mathrm{C}$ by late in the century, while the 0.95 th quantile of daily temperature is projected to increase $2.8^{\circ} \mathrm{C}$ by midcentury and $4.0^{\circ} \mathrm{C}$ by late century (Fig. 3; Table 1).

Average daily precipitation is projected to increase by $7.1 \%$ by midcentury, and $9.9 \%$ by late century (Fig. 4), which is in agreement with Hayhoe et al. (2007), who estimated an increase of between $5 \%$ and $8 \%$ by midcentury and between $7 \%$ and $14 \%$ by late century. Eight of the 12 calendar-month precipitation delta factors are significantly different from 1.0 (no predicted change) for both midcentury and late century. The 0.95 quantile of daily precipitation is projected to increase by $8.9 \%$ by midcentury and $12.5 \%$ by late century, while the 0.99 quantile of daily precipitation is projected to increase by $11.9 \%$ by midcentury and $16.7 \%$ by late century (Fig. 4; Table 1).

The numbers of below freezing days annually are projected to decrease $29 \%$ and $39 \%$ by mid- and late century, respectively, from an average of 116.5 days during the base period (Fig. 5). All months in the two future periods show decreases in snowfall in comparison with the base period (Fig. 6). Cumulative annual snowfall projections near major Vermont ski resorts show decreases from the base period average of $676 \mathrm{~cm}$. Mid- and 

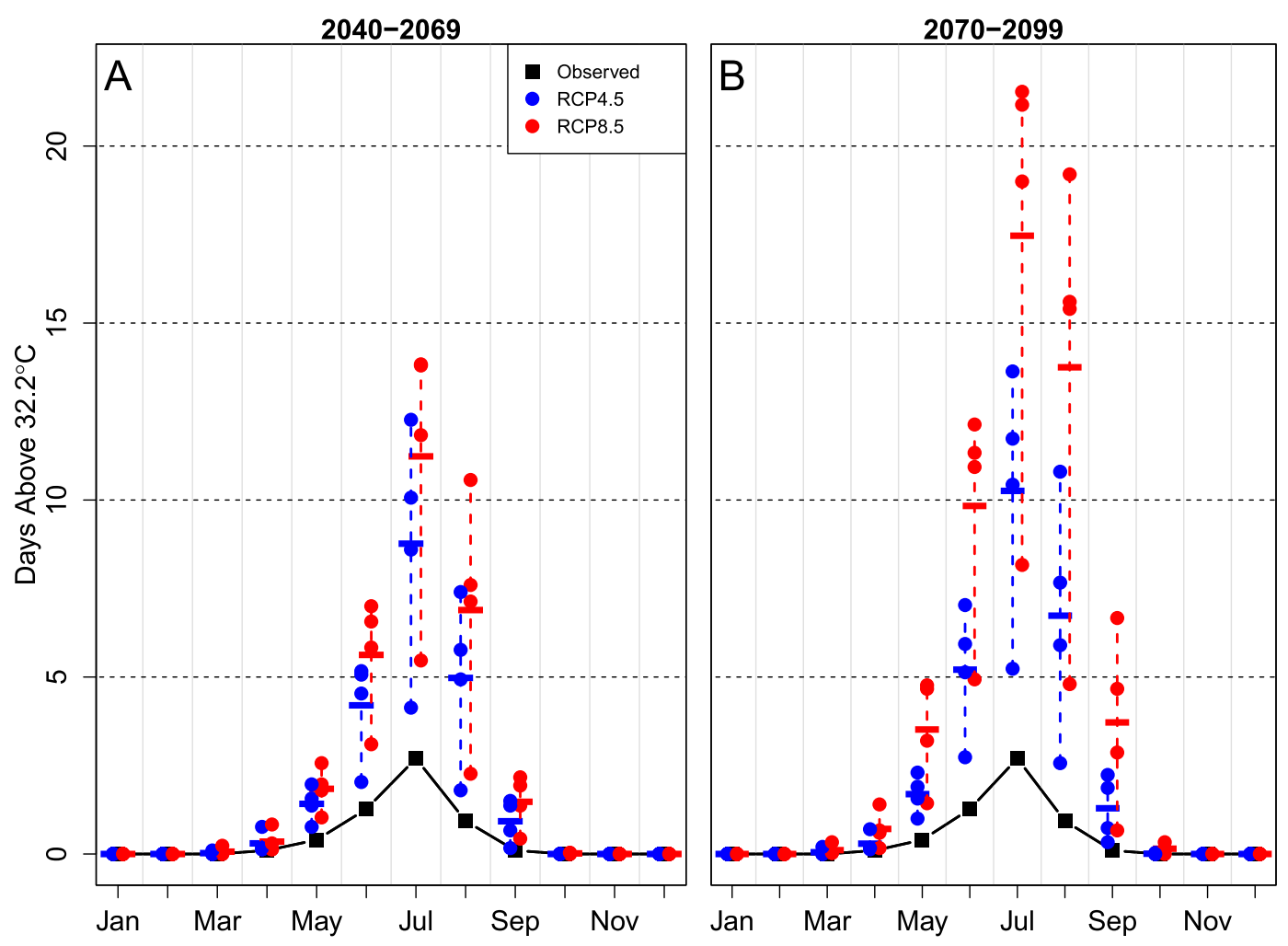

FIG. 7. As in Fig. 5, but for number of "hot" days above $32.2^{\circ} \mathrm{C}\left(90^{\circ} \mathrm{F}\right)$.

late-century projections estimate cumulative snowfall to decrease by $36 \%$ and $50 \%$, respectively (Table 2 ).

In the base period, 5.5 days $\mathrm{yr}^{-1}$ were warmer than $32.2^{\circ} \mathrm{C}\left(90^{\circ} \mathrm{F}\right)$ in the cell containing Burlington. This is projected to increase by $310 \%$ (+18.6 days) by midcentury and $530 \%(+31.9$ days $)$ by late century (Fig. 7). The heat index calculated for the base period was $130 \mathrm{DD}$. This value is projected to increase to 475 DD $(+265 \%)$ by midcentury and to $754 \mathrm{DD}(+480 \%)$ by late in the century (Fig. 8). The length of the growing season during the base period was 140.5 days, which is projected to increase $20 \%$ by midcentury and $31 \%$ by late century (Fig. 9). Days suitable for maple syrup production are projected to decrease and shift in annual cycle. The two peaks found in the base period in autumn and spring both decrease while shifting toward midwinter. Annually the number of suitable days decreases from the base period with 60.3 days to 53 and 49 by mid- and late century, respectively. Interestingly, this decrease in annually suitable days occurs while the months of December and January see a net increase in suitable days of 4.3 and 5.4 by mid- and late century (Fig. 10; Table 2).

Heating and cooling requirements in the study region were calculated in DD. During the twenty-first century heating requirements are projected to decrease by
$19 \%$ and $27 \%$ annually by mid- and late century, respectively, while cooling requirements are expected to increase by $13 \%$ and $40 \%$ over the same period (Fig. 11; Table 2).

April-October was analyzed for statistical differences in rPPET between the base period, midcentury, and late century. By midcentury, four of the seven months show significant decreases in the rPPET relative to the base period, and by late century this increases to five of seven (Fig. 12). To decrease rPPET, either precipitation must decrease or temperature must increase. For the late century, only fall precipitation is not projected to increase significantly. The range of possible precipitation change is falls between $-0.5 \%$ and $+11.7 \%$ by late century. Spring, summer, and autumn temperatures are projected to increase by approximately $4^{\circ} \mathrm{C}$. This indicates that any projected decrease in rPPET is likely being driven by temperature increases (Table 2).

\section{Discussion}

The Lake Champlain basin is likely to experience significant climate change during the twenty-first century. Temperatures are expected to increase by $0.46^{\circ} \mathrm{C} \mathrm{decade}^{-1}$ through late in the century, which is more than double the rate of increase, $+0.19^{\circ} \mathrm{Cdecade}^{-1}$, 

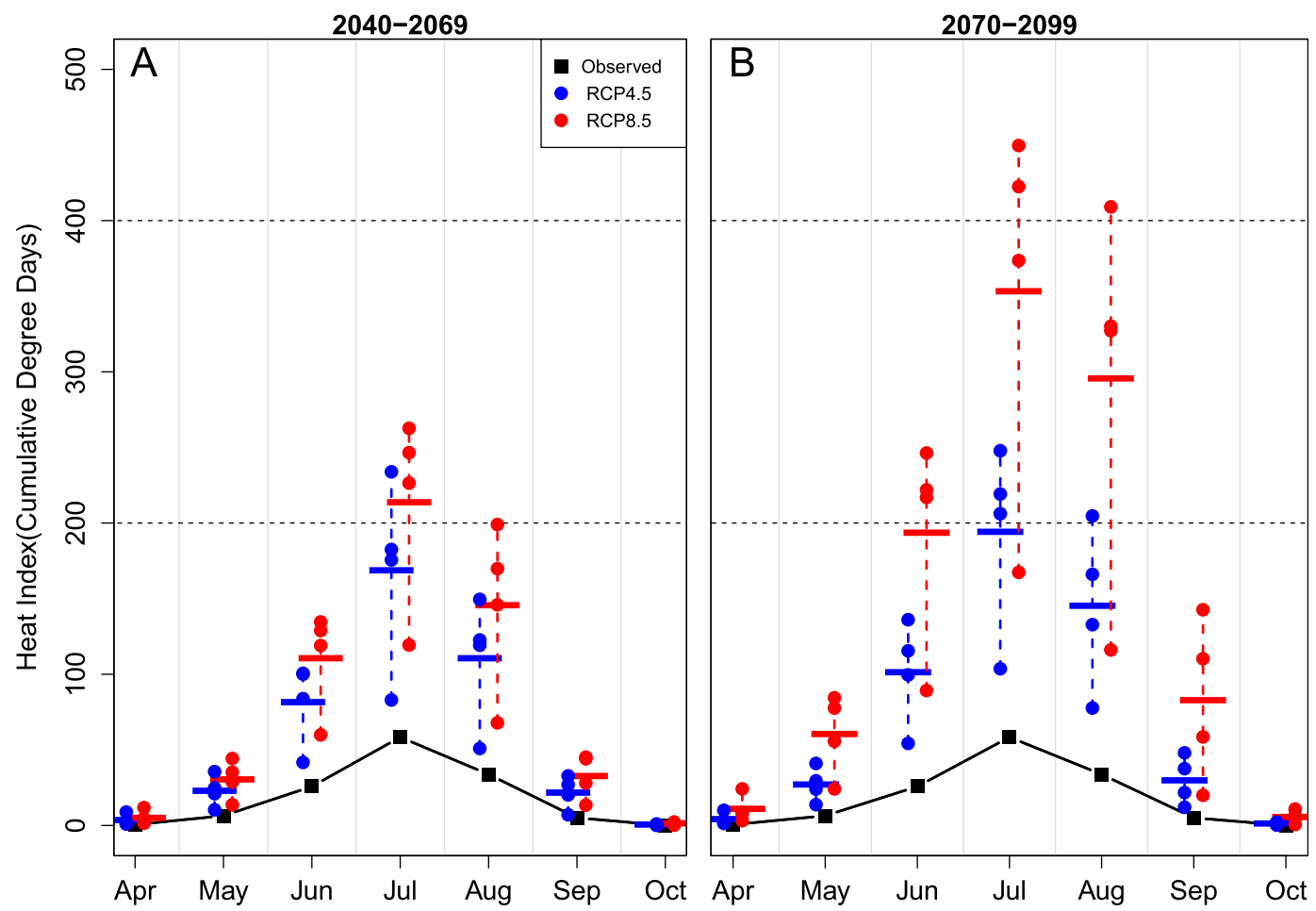

FIG. 8. As in Fig. 5, but for heat index.

in the historic station data. Precipitation is expected to increase $9.9 \%\left(+108 \mathrm{~mm} \mathrm{yr}^{-1}\right)$ by late century, less than one-quarter of the rate found in the historic station data. Because of large multidecadal variability, even the longterm observed precipitation trends may be strongly influenced by unpredictable natural variability. Hayhoe et al. (2007) predicts an increase in temperature of between $2.9^{\circ}$ and $5.3^{\circ} \mathrm{C}$, and an increase in precipitation of between $7 \%$ and $14 \%$ for late in the century. NECIA (2006) predicts similar increases by 2100 with projections

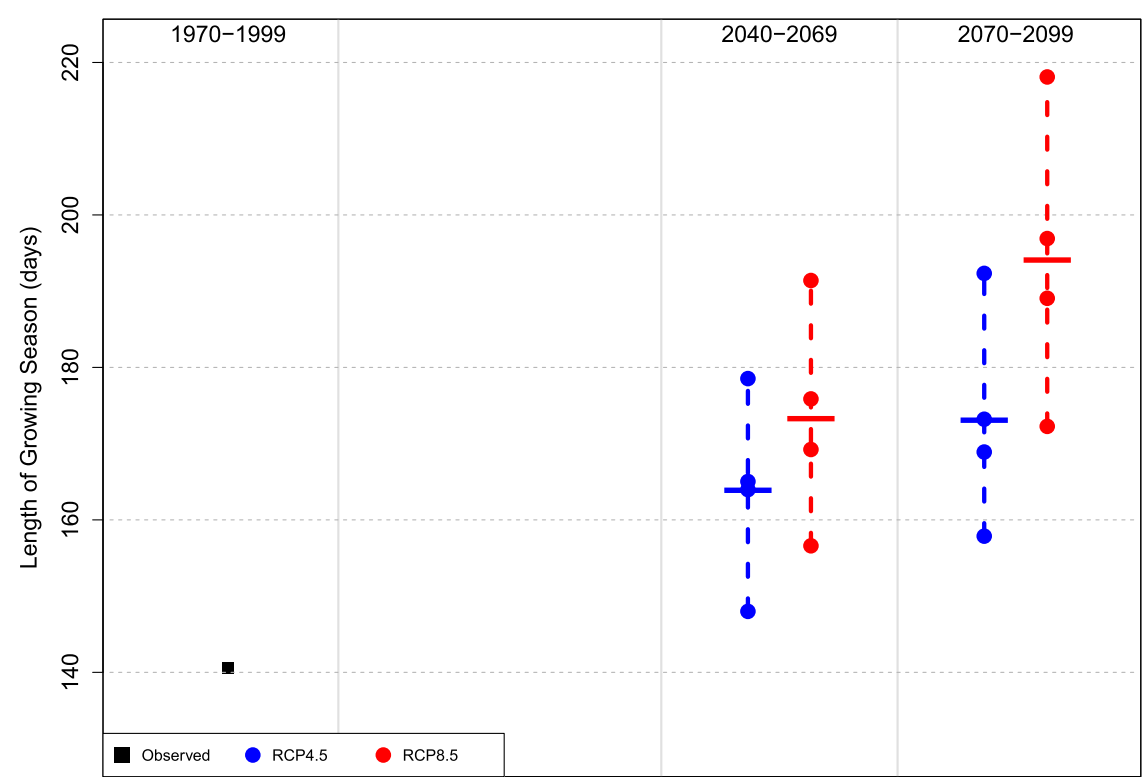

FIG. 9. The projected growing-season length for 2040-69 and 2070-99 for RCP 4.5 and 8.5 relative to the $1970-99$ base period. 

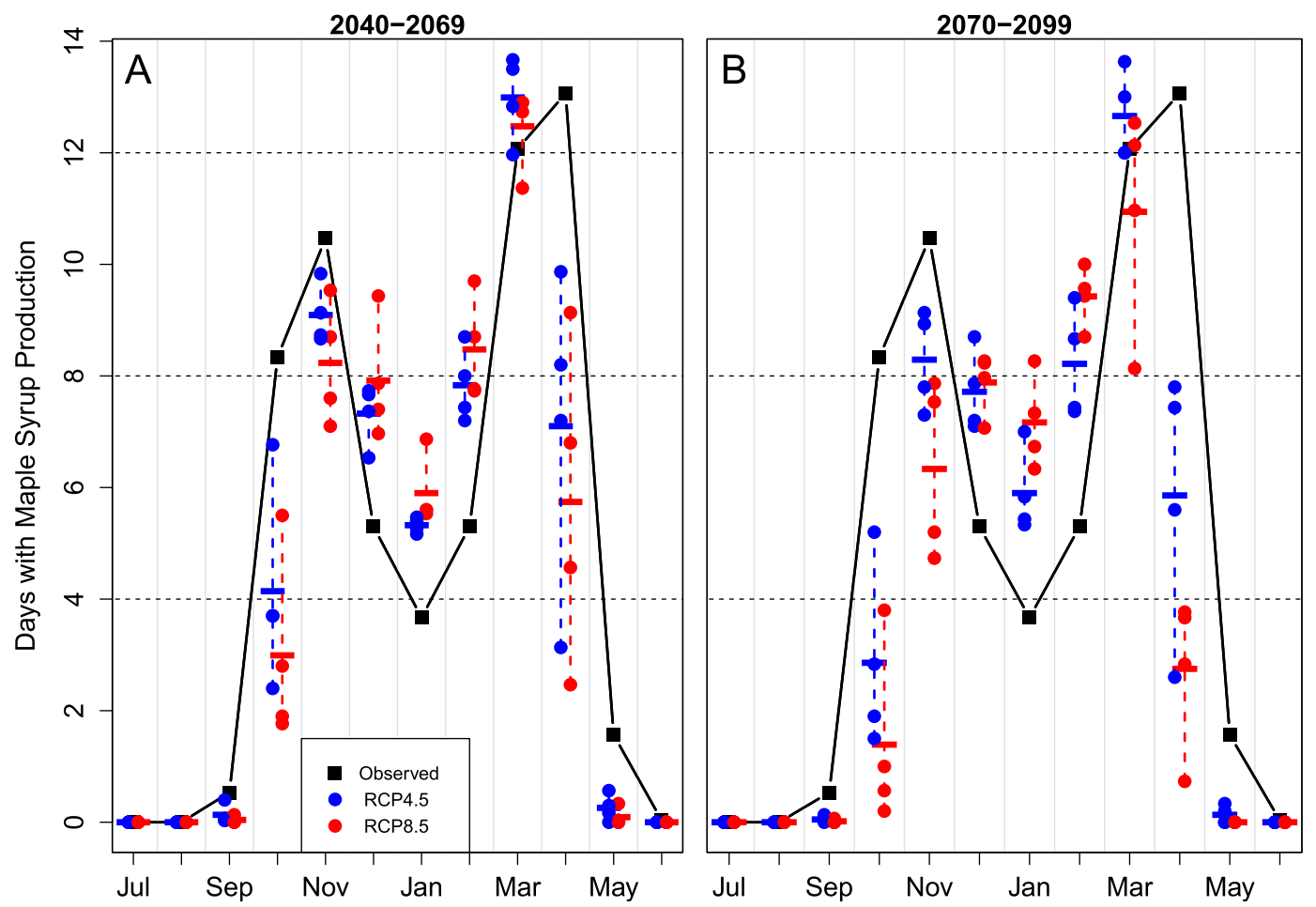

FIG. 10. As in Fig. 5, but for days with maple syrup production.

between approximately $2^{\circ}$ and $7^{\circ} \mathrm{C}$ for temperature and approximately $10 \%$ for precipitation.

The changes in temperature and precipitation are expected to result in an increase in the growing-season aridity (as measured by rPPET). By late century, July's rPPET is projected to decrease below 1.0, meaning potential evapotranspiration exceeds precipitation. This is in agreement with Hayhoe et al. (2007) and NECIA (2006), who both expect an increase in short-duration droughts. A change in rPPET could have ecological and agricultural impacts such as increased water stress on forests, greater susceptibility of trees to insects, decreased crop productivity, and the need for irrigation of agricultural areas (Maracchi et al. 2005; Lindner et al. 2010).

By late in the century both annual snowfall and the number of days below $0^{\circ} \mathrm{C}$ are expected to decrease by $50 \%$ and 45 days, respectively. This projection of decreased snowpack is lower in magnitude than is seen in the findings of Hayhoe et al. (2007); however, this may be explained by this paper's use of only high-elevation grid cells in a more northern climate. The ski industry is likely to be impacted by the decrease in snowfall and the decline in number of freezing days, particularly because temperature increases are most pronounced in the winter months. With less natural snow, the need for snowmaking is expected to increase while the conditions conducive to snowmaking are projected to diminish. However, finerresolution analyses of climate change would be necessary to better project changes in snowfall, particularly in higher-elevation locations that are not well resolved by current climate models. The maple syrup industry is also temperature sensitive, depending on cycles of freezing nights below $1.1^{\circ} \mathrm{C}$ followed by above-freezing days greater than $2.2^{\circ} \mathrm{C}$ for sap to flow in trees (Skinner et al. 2010).

One potential benefit of regional warming is a longer growing season. Projections indicate that the growing season is expected to lengthen $(+43$ days) by late century. This increase in growing-season length agrees with Hayhoe et al. (2007), who found an increase of between 29 and 43 days by late century. With a longer, warmer growing season a larger variety and volume of food may be able to be produced. However, some of the benefit of a longer growing season could be offset by increasing aridity and agriculture pest pressure as temperatures warm. A longer "warm" season and shortened "cold" season is also expected to shift the seasonal energy requirements of the region with less heating yet more cooling required. Late-century projections predict the number of days above $32.2^{\circ} \mathrm{C}$ to be between 35 and 40 days while the annual heat index is expected to increase to between approximately 700 and 800 DD. Projected heat index values in July for late in the century will make 

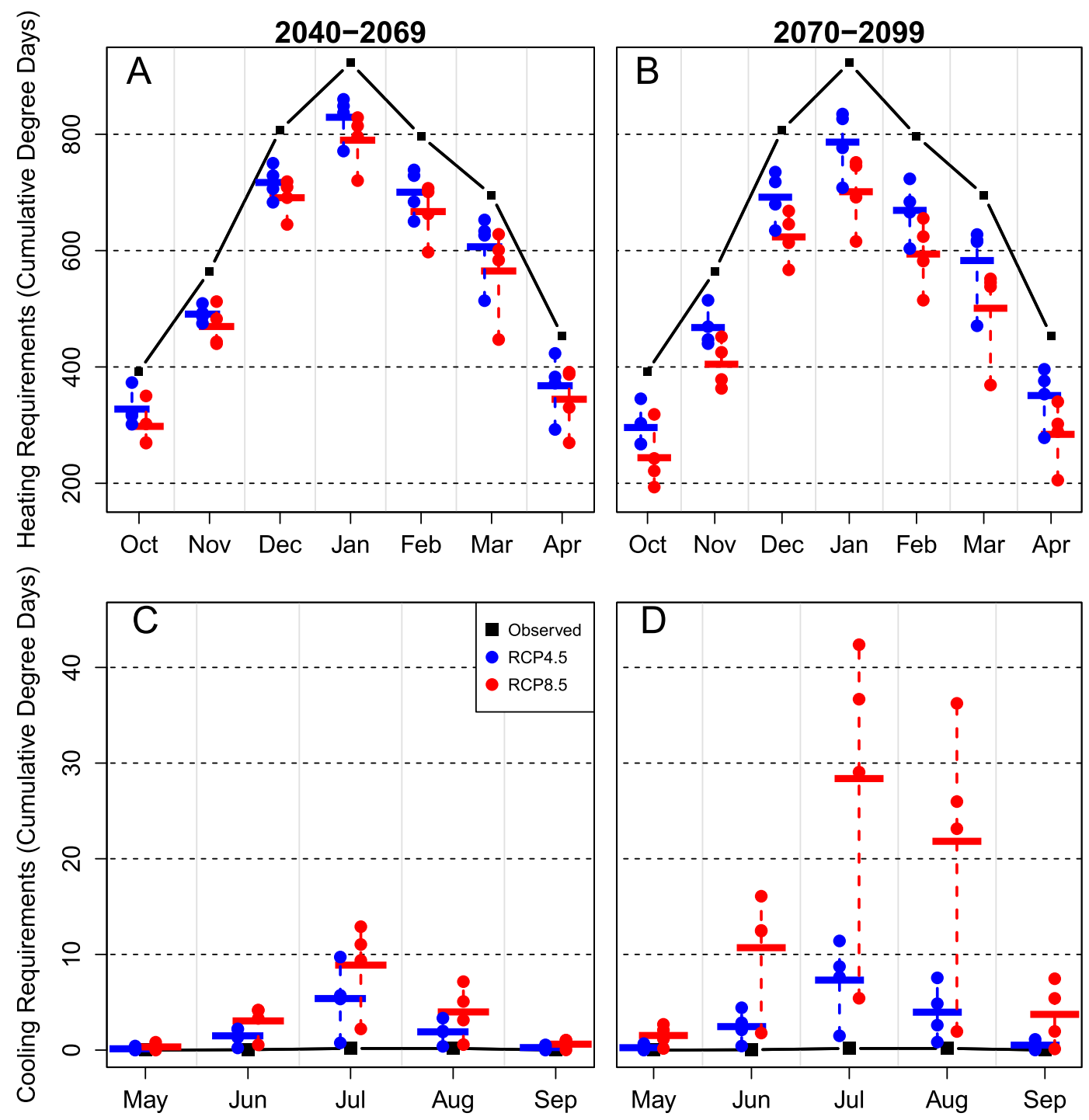

FIG. 11. Projected (a),(b) heating and (c),(d) cooling requirements for (left) 2040-69 and (right) 2070-99 for RCP 4.5 and 8.5 relative to the $1970-99$ base period.

the average day feel approximately $7^{\circ} \mathrm{C}\left(13^{\circ} \mathrm{F}\right)$ warmer. Projections of both days above $32.2^{\circ} \mathrm{C}$ and the heat index largely agree with the findings of the Northeast Climate Change Assessment (NECIA 2006). For industries such as the dairy industry for which animal comfort can be related to production, an increase in the severity of daily heat indices could negatively impact profits (Rosenzweig et al. 2011).

Extreme temperature and precipitation threshold events are likely to increase. By late century, the 95th percentile of daily maximum temperature is projected to increase by $4.0^{\circ} \mathrm{C}$ while the 5 th percentile is projected to increase by $5.3^{\circ} \mathrm{C}$. These increases in temperature quantiles could increase the occurrence of dangerous heat waves. By late in the century, the 99th percentile of daily precipitation is projected to increase by $3.4 \mathrm{~cm}$, which is equivalent to an additional $34000 \mathrm{~m}^{3}$ of liquid precipitation per square kilometer. This increased flow could overwhelm current infrastructure including bridges and culverts as well as increase nutrient loading to Lake Champlain through overland flow and stream bank erosion.

Increasing greenhouse gas concentrations in the atmosphere are expected to impact climate across the Lake Champlain basin with significant hydrologic and ecological consequences. For example, increases in temperature could open the region to biological invasion (Ammunét et al. 2012; Bellard et al. 2013), while shifting the ranges of northern species of trees (McNulty and Aber 2001). Predicting the impacts of climate change is essential for 


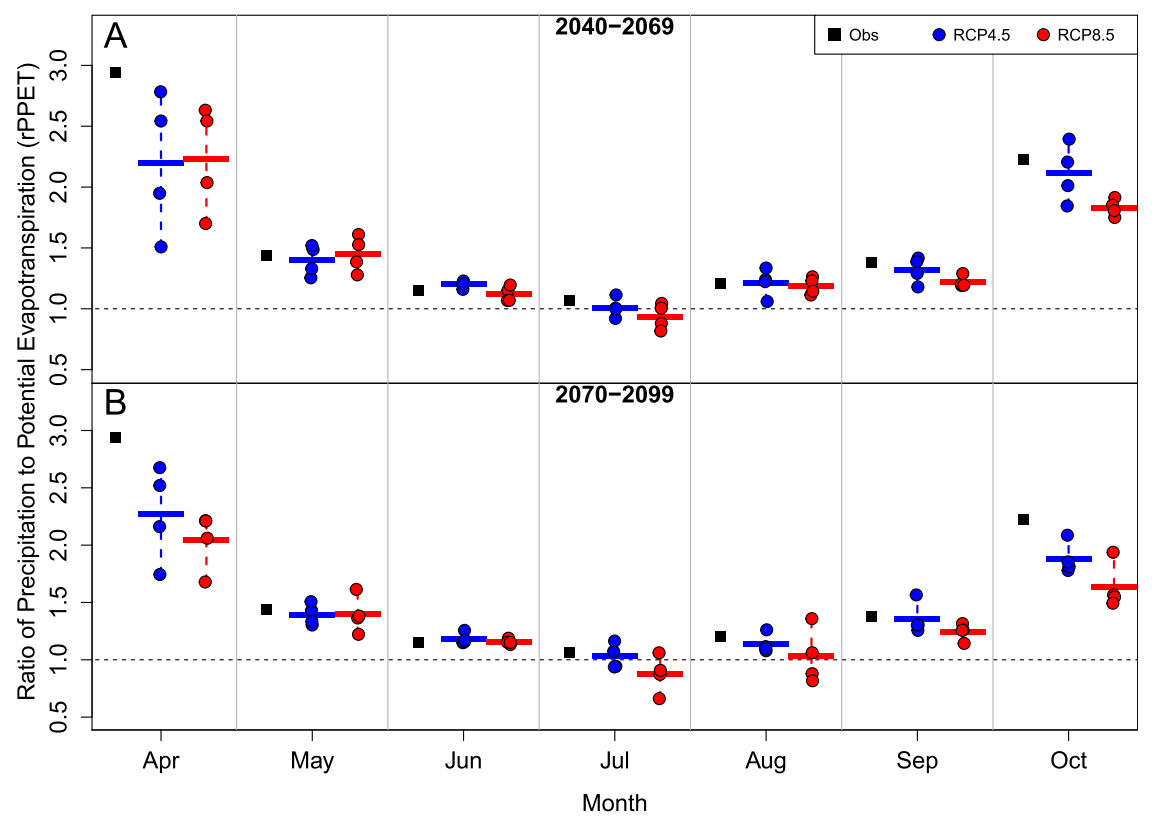

FIG. 12. Projected rPPET for (a) 2040-69 and (b) 2070-99 for RCP 4.5 and 8.5 relative to the 1970-99 base period.

adaptation throughout the Lake Champlain basin. Results from analyses will inform hydrological, ecological, and lake models with the Vermont Experimental Program to Stimulate Competitive Research (VT EPSCoR), as well as provide the basis for adaptation planning in the region. It is noted that this study has focused on quantiles and means of precipitation but aspects of climate change must also be carefully considered including tropical and posttropical cyclones such as Hurricane Irene, and the potential for changes in midlatitude climate due to factors such as reductions in Arctic sea ice (Liu et al. 2012, 2013), which are both poorly simulated by GCMs. Future work includes finer-scale downscaling in this topographically diverse region; for example, using statistical lapse rate relationships and regional climate model simulations to explore the future climate of the high-elevation portions of the Lake Champlain basin domain and by better resolving processes influencing regional climate in the focal region.

Acknowledgments. This work was supported by Vermont EPSCoR through NSF Award EPS-1101317. Many thanks are given to Levi Brekke, Ed Maurer, and Tom Pruitt for their assistance with the BCCA data used in this analysis.

\section{REFERENCES}

Ahmed, K. F., G. Wang, J. Silander, A. M. Wilson, J. M. Allen, R. Horton, and R. Anyah, 2012: Statistical downscaling and bias correction of climate model outputs for climate change impact assessment in the US northeast. Global Planet. Change, 110, 320-332, doi:10.1016/j.gloplacha.2012.11.003.

Ammunét, T., T. Kaukoranta, K. Saikkonen, T. Repo, and T. Klemola, 2012: Invading and resident defoliators in a changing climate: Cold tolerance and predictions concerning extreme winter cold as a range-limiting factor. Ecol. Entomol., 37, 212 220, doi:10.1111/j.1365-2311.2012.01358.x.

Beckage, B., B. Osborne, D. G. Gavin, C. Pucko, T. Siccama, and T. Perkins, 2008: A rapid upward shift of a forest ecotone during 40 years of warming in the Green Mountains of Vermont. Proc. Natl. Acad. Sci. USA, 105, 4197-4202, doi:10.1073/ pnas.0708921105.

Bellard, C., W. Thuiller, B. Leroy, P. Genovesi, M. Bakkenes, and F. Courchamp, 2013: Will climate change promote future invasions? Global Change Biol., 19, 3740-3748, doi:10.1111/ gcb.12344.

Brekke, L., B. Thrasher, E. Maurer, and T. Pruitt, 2013: Downscaled CMIP3 and CMIP5 climate projections: Release of downscaled CMIP5 climate projections, comparison with preceding information, and summary of user needs. Technical Service Center, Bureau of Reclamation, U.S. Department of the Interior, Denver, CO, 47 pp. + appendixes. [Available online at http://gdo-dcp.ucllnl.org/downscaled_cmip_projections/techmemo/ downscaled_climate.pdf.]

Burroughs, H. B., and S. J. Hansen, 2004: Managing Indoor Air Quality. CRC Press, $361 \mathrm{pp}$.

Groisman, P. Ya., R. W. Knight, D. R. Easterling, T. R. Karl, G. C. Hegerl, and V. N. Razuvaev, 2005: Trends in intense precipitation in the climate record. J. Climate, 18, 1326-1350, doi:10.1175/JCLI3339.1.

Hayhoe, K., and Coauthors, 2007: Past and future changes in climate and hydrological indicators in the US Northeast. Climate Dyn., 28, 381-407, doi:10.1007/s00382-006-0187-8.

Hidalgo, H. G., M. D. Dettinger, and D. R. Cayan, 2008: Downscaling with constructed analogues: Daily precipitation and temperature fields over the United States. California Energy 
Comm. PIER Final Project Rep. CEC-500-2007-123, 48 pp. [Available online at http://www.energy.ca.gov/2007publications/ CEC-500-2007-123/CEC-500-2007-123.PDF.]

Horton, R., and Coauthors, 2014: Northeast. Climate Change Impacts in the United States: The Third National Climate Assessment, J. M. Melillo, T. C. Richmond, and G. W. Yohe, Eds., U.S. Global Change Research Program, 371-395. [Available online at http://nca2014.globalchange.gov/downloads.]

Keim, B. D., M. R. Fischer, and A. M. Wilson, 2005: Are there spurious precipitation trends in the United States Climate Division database? Geophys. Res. Lett., 32, L04702, doi:10.1029/ 2004 GL021985.

Kimball, J. S., S. W. Running, and R. Nemani, 1997: An improved method for estimating surface humidity from daily minimum temperature. Agric. For. Meteor., 85, 87-98, doi:10.1016/ S0168-1923(96)02366-0.

Knutti, R., and J. Sedláček, 2012: Robustness and uncertainties in the new CMIP5 climate model projections. Nature Climate Change, 3, 369-373, doi:10.1038/nclimate1716.

Lavine, M., 2009: Introduction to Statistical Thought. Orange Grove Texts Plus, 434 pp.

Lawrence, M. G., 2005: The relationship between relative humidity and the dewpoint temperature in moist air: A simple conversion and applications. Bull. Amer. Meteor. Soc., 86, 225-233, doi:10.1175/BAMS-86-2-225.

Lindner, M., and Coauthors, 2010: Climate change impacts, adaptive capacity, and vulnerability of European forest ecosystems. For. Ecol. Manage., 259, 698-709, doi:10.1016/ j.foreco.2009.09.023.

Liu, J., J. A. Curry, H. Wang, M. Song, and R. M. Horton, 2012: Impact of declining Arctic sea ice on winter snowfall. Proc. Natl. Acad. Sci. USA, 109, 4074-4079, doi:10.1073/ pnas.1114910109.

_- M. Song, R. M. Horton, and Y. Hu, 2013: Reducing spread in climate model projections of a September ice-free Arctic. Proc. Natl. Acad. Sci. USA, 110, 12 571-12576, doi:10.1073/ pnas.1219716110.

Maracchi, G., O. Sirotenko, and M. Bindi, 2005: Impacts of present and future climate variability on agriculture and forestry in the temperate regions: Europe. Climatic Change, 70, 117-135, doi:10.1007/s10584-005-5939-7.

Maurer, E. P., and H. G. Hidalgo, 2008: Utility of daily vs. monthly large-scale climate data: An intercomparison of two statistical downscaling methods. Hydrol. Earth Syst. Sci., 12, 551-563, doi:10.5194/hess-12-551-2008.

- - , T. Das, M. D. Dettinger, and D. R. Cayan, 2010: The utility of daily large-scale climate data in the assessment of climate change impacts on daily streamflow in California. Hydrol. Earth Syst. Sci., 14, 1125-1138, doi:10.5194/ hess-14-1125-2010.

McNulty, S. G., and J. D. Aber, 2001: U.S. National Climate Change Assessment on forest ecosystems: An introduction.
Bioscience, 51, 720-722, doi:10.1641/0006-3568(2001)051[0720: UNCCAO]2.0.CO;2.

Menne, M. J., I. Durre, R. S. Vose, B. E. Gleason, and T. G. Houston, 2012: An overview of the Global Historical Climatology Network-Daily Database. J. Atmos. Oceanic Technol., 29, 897-910, doi:10.1175/JTECH-D-11-00103.1.

Moss, R. H., and Coauthors, 2010: The next generation of scenarios for climate change research and assessment. Nature, 463, 747756, doi:10.1038/nature08823.

NCDC, cited 2013: Approximate snowfall amounts at specified temperature ranges. National Climatic Data Center. [Available online at http://www.erh.noaa.gov/box/tables/snowfallmeltwater.html.]

NECIA, 2006: Climate change in the U.S. northeast: A report of the Northeast Climatic Impacts Assessment. Union of Concerned Scientists, 35 pp. [Available online at http://www. climatechoices.org/assets/documents/climatechoices/NECIA_ climate_report_final.pdf.]

Pealer, S., 2012: Lessons from Irene: Building resiliency as we rebuild. Climate Change Team, Vermont Agency of Natural Resources, 8 pp. [Available online at http://www.anr.state.vt. us/anr/climatechange/Pubs/Irene_Facts.pdf.]

Plummer, M., 2003: JAGS: A program for analysis of Bayesian graphical models using Gibbs sampling. Third Int. Workshop on Distributed Statistical Computing, Vienna, Austria, Austrian Association for Statistical Computing and the R Foundation for Statistical Computing. [Available online at http://www.ci.tuwien.ac.at/Conferences/DSC-2003/Drafts/ Plummer.pdf.]

Rawlins, M. A., R. S. Bradley, and H. F. Diaz, 2012: Assessment of regional climate model simulation estimates over the northeast United States. J. Geophys. Res. Atmos., 117, D23112, doi:10.1029/2012JD018137.

Rosenzweig, C., and Coauthors, 2011: Responding to climate change in New York State: Synthesis report. New York State Energy Research and Development Authority Tech. Rep. 11-18, Albany, NY, 53 pp. [Available online at http:// nyserda.ny.gov/Publications/Research-and-Development/ Environmental/EMEP-Publications/Response-to-ClimateChange-in-New-York.aspx.]

Skinner, C. B., A. T. DeGaetano, and B. F. Chabot, 2010: Implications of twenty-first century climate change on northeastern United States maple syrup production: Impacts and adaptations. Climatic Change, 100, 685-702, doi:10.1007/s10584-009-9685-0.

Stroeve, J. C., V. Kattsov, A. Barrett, M. Serreze, T. Pavlova, M. Holland, and W. N. Meier, 2012: Trends in Arctic sea ice extent from CMIP5, CMIP3 and observations. Geophys. Res. Lett., 39, L16502, doi:10.1029/2012GL052676.

Thornthwaite, C. W., 1948: An approach toward a rational classification of climate. Geogr. Rev., 38, 55-94, doi:10.2307/210739.

Trombulak, S. C., and R. Wolfson, 2004: Twentieth-century climate change in New England and New York, USA. Geophys. Res. Lett., 31, doi:10.1029/2004GL020574. 